\title{
Self-Ingroup Overlap in the Face of Mortality Salience ${ }^{1)}$
}

\author{
Takumi WATANABE and Kaori KARASAWA \\ University of Tokyo
}

\begin{abstract}
This article examines the prediction derived from terror management theory that mortality salience increases self-ingroup overlap. The theory provides the notion that people support their cultural worldview when mortality is salient. The authors tested how people in fear of death become attached to their ingroups with respect to cognitive overlap of the self and ingroups. The overlap was measured by assessing the mental representations between the self and ingroup. Response time analysis showed that participants in the mortality salient condition rated self-ingroup matching traits faster than they did mismatching traits, whereas mortality salience did not affect self-outgroup overlap. These results confirmed our hypothesis that the fear of death invokes enhanced selfingroup overlap whereby people defend their cultural worldview. The findings were discussed in the context of the relationship between terror management and overlaps of the self and ingroup.
\end{abstract}

Key Words: self, ingroup, overlap, mortality salience, terror management

Research has shown that people tend to differentiate themselves from others on the basis of their group membership. Such group membership often becomes one of the crucial determinants that guide people's cognition, affect, and behavior toward others. According to social identity theory (Tajfel \& Turner, 1979) and self-categorization theory (Turner, Hogg, Oakes, Reicher, \& Wetherell, 1987), people derive their self-concepts and self-knowledge from their ingroups and begin to develop a group-based social identity in addition to their own personal identities. When people see themselves as a member of a group, they conform to ingroup norms with regard to thoughts and behaviors. As a result, these processes would form a basis for overlapping mental representations between the self and ingroup.

In accordance with this idea, Smith and his collaborators proposed a way of measuring overlaps of the self and ingroup concepts (Smith \& Henry, 1996; Smith, Coats, \& Walling, 1999). From a connectionist perspective, they bor- rowed the paradigm from Aron, Aron, Tudor, and Nelson (1991), who studied of personal closeness in intimate relationships. Using this method, Smith and colleagues examined the cognitive association link between self-concepts and ingroup concepts, which is reflected as a difference in response latency. Specifically, if the trait judgments of self are facilitated by matches with the ingroup and inhibited by mismatches, this could be evidence that mental representations of the self and ingroup overlap.

In the Smith et al. (1999) study, for example, participants first completed a paper-pencil task, in which they rated several trait descriptions of the self as well as of the ingroup members. Participants then rated ingroup-descriptions again, this time on the computer. Matches and mismatches were identified from the first trait evaluation task. Reaction time analyses showed that participants determined the ingroup descriptiveness of the traits more quickly when the self-ingroup matching traits were presented. Previous

1) We would like to thank Misato Kuruma and Hiroko Ogasawara for their cooperation with the experiment. 
research on this methodology has indicated that mental representation of the self and ingroup overlaps under various intergroup conditions, which include less salient but not novel ingroups. In contrast, however, studies have shown that there is no overlap between the self and outgroup. Building on these evidences, Smith and collaborators concluded that the results demonstrated the process of self-stereotyping (Smith \& Henry, 1996; Smith et al., 1999), while others interpreted the same effects as evidence of self-anchoring (Otten \& Epstude, 2006; Cadinu \& De Amicis, 1999).

Although these studies give ample evidence that the self and ingroup are linked in cognitive network, these overlaps could involve motivational processes as well. For example, people may be especially apt to merge with ingroups for the purpose of self-protection because the connection with ingroups could provide comfort and validate the selfconcepts. According to Baumeister and Leary (1995), connection with others is considered to be one of the most fundamental needs of human beings, and ingroups could serve to fulfill the needs for belongings and affiliation. In a similar vein, Correll and Park (2005) proposed that ingroups have functions to maintenance self-worth and people try to regulate the self-state by seeking the connection with ingroups. Knowles and Gardner (2008) further found that an ingroup membership has a benefit of boosting one's sense of belonging, which elicits high self-esteem and positive mood. Given that group memberships protect individual's self-state, motivational pressures on the self are also likely to affect the cognitive overlap between the self and ingroup. In specific, we predict that when a person's selfconcept is threatened, he or she would increase overlaps of the self and ingroup to restore their own threatened selfimage.

In this study, our primary interest is to examine these selfmaintenance functions of self-ingroup overlap. For this purpose, terror management theory (Greenberg, Pyszczynski, \& Solomon, 1986) will serve as a theoretical framework. According to the theory, only humans are capable to be aware of the inevitability of their own death, and they are biologically driven to self-preservation. In order to deal with such self-threat, people manage the terror by cultural anxiety buffer, which consists of an individual's cultural worldview and self-esteem. Cultural worldview provides the world with meaning, order, and stability, and it also pro- vides the promise of literal or symbolic immortality to those who meet prescribed standards of value. People invest in cultural worldview that gives the individual with these meaning systems and explains his or her existence. Selfesteem, the second component of the anxiety buffer, means a sense of personal value, and it is conceptualized as the perception that one is a significant member of a meaningful world that functions ultimately to serve protection from the fear of death.

The claim of terror management theory is supported by two lines of research hypotheses: (a) anxiety-buffering hypothesis, and (b) mortality salience hypothesis. The anxiety-buffering hypothesis suggests that because selfesteem could serve the function of self-protection against the threats of death, enhanced self-esteem should reduce proneness to exhibit anxiety or anxiety-related behavior in response to threats. Studies have shown that increased self-esteem reduce self-reported anxiety and anxietyrelated defensive efforts (Greenberg, Solomon, Pyszczynski, Rosenblatt, Burling, Lyon, Simon, \& Pinel, 1992; Greenberg, Pyszczynski, Solomon, Pinel, Simon, \& Jordan, 1993). With regard to the mortality salience hypothesis, the theory predicts that reminding people of their own death should increase their need to bolster faith in cultural worldview. Studies examining the mortality salience hypothesis have shown that mortality salience leads to increased tendency to behave in accordance with one's values and cultural norms (Taubman Ben-Ari, Florian, \& Mikulincer, 1999; Greenberg, Simon, Porteus, Pyszczynski, \& Solomon, 1995). Additionally, studies have confirmed that when people are made aware of the inevitability of death, they express greater attraction to those who praise their cultural worldview and decreased attraction to those who criticize the cultural worldview (Greenberg, Pyszczynski, Solomon, Rosenblatt, Veeder, Kirkland, \& Lyon, 1990; Dechesne, Janssen, \& van Knippenberg, 2000).

Guided by these fundamental theoretical assumptions, it is predicted that when mortality is salient, people will become attached to ingroups more strongly with respect to cognitive links. The overlap of the self and ingroup could benefit from coping with threats about death and we investigate this proposal by testing the hypothesis that mortality salience would facilitate the cognitive overlap of the self and ingroup. Support for this prediction derives in part from Castano, Yzerbyt, Paladino, and Sacchi's (2002) work dem- 
onstrating the effects of mortality salience on group identification and entitativity. They found evidence that participants who were reminded of their thoughts about death identified with their ingroup more strongly, and they perceived greater ingroup entitativity. By strengthening ties to the ingroup and perceiving it as a permanent entity, the participants should have attempted to reduce deathrelated anxiety. Support also comes from Harmon-Jones, Greenberg, Solomon, and Simon's (1996) work which addressed the cultural worldview defense in the context of minimal group paradigm (Tajfel, Billig, Bundy, \& Flament, 1971). From a terror management perspective, their work has shown that mortality salience increases ingroup identification. Thus, associations with ingroups could become an important means of maintaining psychological equanimity.

Although there is support for some of the basic assumptions that ingroups serve the functions of cultural worldview defense, no studies have addressed this issue in the context of cognitive overlaps. The current study expands on prior work by focusing on these cognitive links between the self and ingroup, and examines how the mental representation of the two concepts overlaps under mortality salience manipulation. We predict self-ingroup overlap will be enhanced in the face of mortality salience. Strong relationship between the self and ingroup would result in increased sense of self-worth and it could be a basis for a sense of death transcendence.

\section{Method}

\section{Participants and Design}

Participants were 39 undergraduates at the University of Tokyo (27 men, 12 women, $M_{\text {age }}=20.33$ years, $S D=0.84$ ). There were no significant differences between male and female participants in any of the results reported below; therefore, the gender issue will not be discussed further. We included mortality salience manipulation as an independent variable, and participants were randomly assigned to either the mortality salient or control condition.

\section{Procedure}

The procedure was partially adopted from Smith et al. (1999). Upon arrival at the laboratory, participants were told that they would take part in a computer-assisted experiment and that they would make a series of judgments about themselves and groups. Participants were then seated in front of a computer and were explained that all of the instructions were given through the computer. The experiment consisted of mortality salience manipulation, group categorization, a trait evaluation task, and a response time task, in a sequential order.

The mortality salience treatment was identical to that used in Nodera, Karasawa, Numazaki, and Takabayashi (2007), which varied the items in the questionnaire between the mortality salient and control condition. Namely, the scale in the mortality salient condition consisted of 25 questions that dealt with various aspects of fear of death, and the participants were reminded of thoughts of death. The questionnaire asked participants to rate their degree of agreement or disagreement with each statement. Sample items are "Death is a last agonizing moment," and "Death leaves the family to fend for itself." In contrast, control participants answered a different set of 25 items, which addressed their eating habits. Examples are "I often eat meat rather than fish," and "I drink once a week." Thus, the questionnaire in the control condition was totally unrelated to thoughts of death. Although typical studies in this area induce participants to think of their own mortality (e.g., "Please briefly describe the emotions that the thought of your own death arouses in you”), it has been well established that the death-related scale provides the same effects as other mortality salience treatments (Florian, Mikulincer, \& Hirschberger, 2001; Greenberg, Simon, Harmon-Jones, Solomon, Pyszczynski, \& Lyon, 1995). These treatments are thought to heighten death-thought accessibility, and would lead to increased tendency to defend the cultural worldview.

We then used the typical minimal group procedure to make artificial laboratory groups (Tajfel et al., 1971). By using the minimal groups, we avoided potential confounds of participants' prior knowledge in the trait evaluation task. Following several screens with instructions, participants were presented with pairs of paintings on a computer screen. For each of 10 pairs, they were asked to choose their preferred painting by clicking on it with the mouse. Participants were told that each pair contained one painting by Cooper and one painting by Thompson, but which painting was painted by which artist was not revealed. At the end of this task, they were given fictitious feedback about their own group membership. Namely, all participants were randomly assigned to either the Cooper group or Thompson group, ostensibly on the basis of art preference. 
The instructions on the computer screen explained that the purpose of this study was to investigate the relationship between artistic preference and personality estimation, and that participants were to guess the characteristics of general ingroup and outgroup member in the proceeding tasks.

Later, participants evaluated themselves and both ingroup and outgroup members with regard to 60 trait adjectives. Specifically, they were asked to rate whether a given trait was descriptive of each target, using a 7 -point scale ( $1=n o t$ at all and $7=$ extremely). The targets were the self, ingroup member, and outgroup member. The order of the three targets was counterbalanced across participants. The traits included 30 positive and 30 negative attributes that were selected and created based on Saito, Nakamura, Endo, and Yokoyama (2001). Examples of positive traits are kind and creative, while negative traits included cold and unfriendly. These traits were presented in a completely random order.

After the trait evaluation task, participants completed the response time task for the same 60 traits, indicating whether or not a presented trait was characteristic of ingroup and outgroup member, respectively. The order of the two targets was counterbalanced across participants. This time, they were allowed to respond in either yes (descriptive) or no (non-descriptive). It was emphasized that they should press the respective button on the keyboard as quickly and accurately as possible in order to state whether or not a presented trait was descriptive of the target. The trait words appeared at the center of the computer screen in a random order, and each trait word remained on the screen until the participant registered a response. The trial interval was $500 \mathrm{~ms}$, and the computer measured response latency for each trait.

In order to check whether the group categorization was salient for the participants, they completed a manipulation check item that was presented on the computer. Specifically, the question was "I believe that I preferred the paintings by..."; participants chose the name of the artist, either Cooper or Thompson. Finally, they were thanked and debriefed.

\section{Results}

\section{Self and Group Descriptiveness}

Inspection of the answers to the manipulation check item revealed that all participants correctly answered their ingroup names (Cooper or Thompson); therefore, the group categorization was effective to the participants and they appeared to believe the manipulation.

As in previous research (Smith \& Henry, 1996; Smith et al., 1999), 7-point scales in the evaluation task were dichotomized with respect to their self-descriptiveness, ingroup descriptiveness, and outgroup descriptiveness. For self-descriptiveness, ratings of 5-7 were regarded as descriptive of self (yes response) while ratings of 1-3 were regarded as non-descriptive of self ( $n o$ response). Responses that had a rating of 4 on the 7-point scales were treated as missing and were excluded from the analysis. Similarly, for ingroup and outgroup descriptiveness, ratings of $5-7$ were regarded as descriptive of the target group (yes response), whereas ratings of 1-3 were regarded as non-descriptive (no response). For each participant, the 60 trait words were organized into two categories: (a) those rated as descriptive of both the self and the target group or rated as non-descriptive of both the self and the target group, and (b) those rated as descriptive of the self but not the target group or rated as descriptive of the target group but not the self. The traits in the former category were treated as matching traits because participants made coherent judgments of the self and the target group. In comparison, those in the latter category were treated as mismatching because the judgments of trait-descriptiveness were different between the self and the target group.

\section{Response Time Analysis}

Prior to the analysis, response time was log-transformed to obtain a more normal distribution (Fazio, 1991). For ease of interpretation, however, the results are presented in ms. Then we computed the individual mean response times by 2 (Target Group: ingroup vs. outgroup) $\times 2$ (Trait Type: match vs. mismatch), and these mean response times served as the dependent variable in the following analyses. Preliminary analyses showed that participants' group name (Cooper, Thompson), the order of evaluation (self first, ingroup first, outgroup first), and the trait valence (positive, negative) had no main effects or interaction effects on any of the measures in the analysis reported here. Consequently, we ignored these three factors in subsequent analyses.

We conducted a 2 (MS: mortality salient vs. control) $\times 2$ (Target Group: ingroup vs. outgroup) $\times 2$ (Trait Type: match vs. mismatch) analysis of variance with repeated measures on the last two factors. This analysis revealed two signifi- 




Figure 1. Response time by MS $\times$ Trait Type for the ingroup target

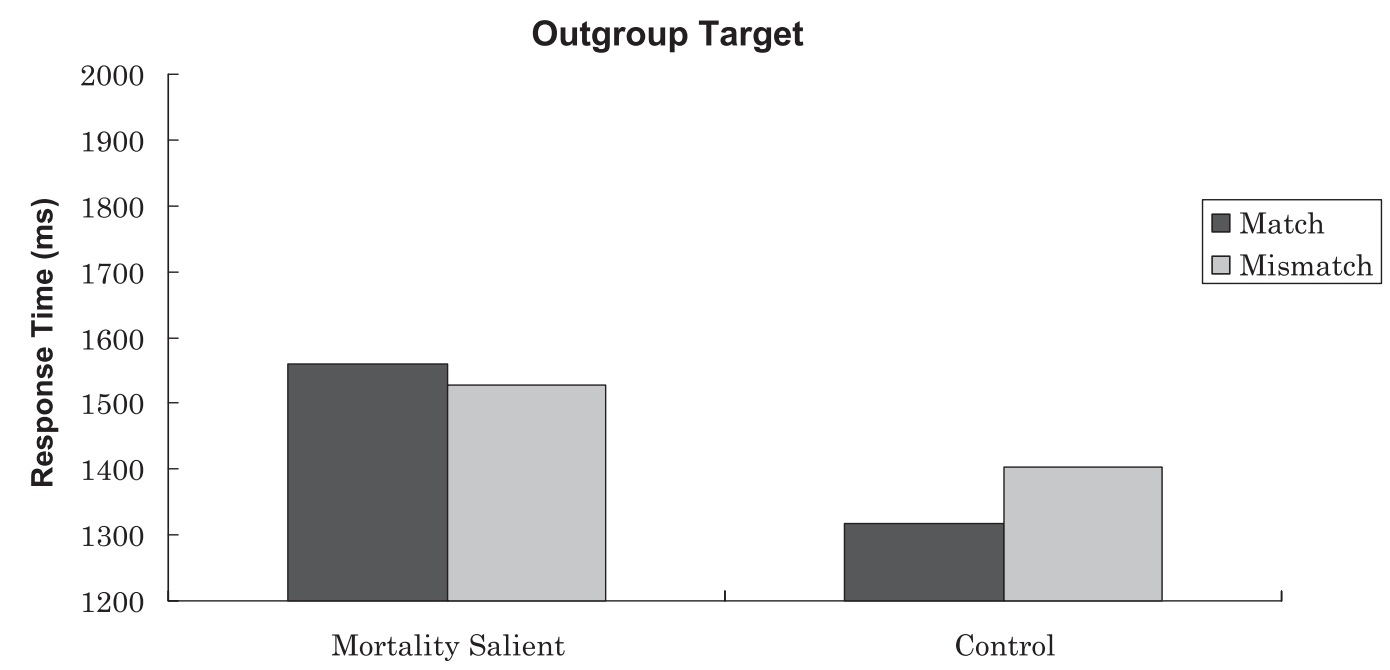

Figure 2. Response time by MS $\times$ Trait Type for the outgroup target

cant main effects. A main effect of $\mathrm{MS}, F(1,37)=4.90$, $p<.05$, indicated that the participants responded faster to the trait descriptiveness in the control condition $(M=$ $1328.23 \mathrm{~ms} ; S D=532.57 \mathrm{~ms}$ ) than in the mortality salient condition ( $M=1612.57 \mathrm{~ms} ; S D=412.72 \mathrm{~ms})$. There was also a main effect of Trait Type, $F(1,37)=5.22, p<.05$, showing that the participants decided more quickly whether a trait described the group when the self and the target group matched ( $M=1396.13 \mathrm{~ms} ; S D=513.29 \mathrm{~ms}$ ) than when the self and the target group were mismatched $(M=1493.63$ $\mathrm{ms} ; S D=525.64 \mathrm{~ms}$ ). More importantly, these effects were qualified by a predicted three-way interaction of MS $\times$ Target Group $\times$ Trait Type, $F(1,37)=4.50, p<.05$. Additional tests revealed that this effect was driven by a significant two-way interaction of $\mathrm{MS} \times$ Trait Type for the ingroup condition, $F(1,74)=4.85, p<.05$, while the same interaction was not significant for the outgroup condition, $F(1,74)=0.50$, n.s.

Figure 1 displays the mean response times by $\mathrm{MS} \times$ Trait Type for the ingroup target. Simple effects tests for MS $\times$ Trait Type revealed that in the mortality salient condi- 
tion, responses for the self-ingroup matching traits ( $M=1507.98 \mathrm{~ms} ; S D=411.04 \mathrm{~ms}$ ) were considerably faster than responses for the mismatching traits $(M=1852.86 \mathrm{~ms}$; $S D=671.49 \mathrm{~ms}), F(1,74)=12.77, p<.001$. In the control condition, however, the matching traits $(M=1283.92 \mathrm{~ms}$; $S D=655.02 \mathrm{~ms})$ and mismatching traits $(M=1309.01 \mathrm{~ms}$; $S D=605.03 \mathrm{~ms}$ ) did not differ from each other in their response speed, $F(1,74)=0.21$, n.s. Compared with the ingroup target condition, there were no self-outgroup matching effects regardless of the mortality salience manipulation. As shown in Figure 2, the response time difference between the matching traits $(M=1560.38 \mathrm{~ms} ; S D=485.27$ $\mathrm{ms})$ and mismatching traits $(M=1529.05 \mathrm{~ms} ; S D=377.76$ $\mathrm{ms}$ ) in the mortality salient condition and the difference between the matching traits $(M=1316.26 \mathrm{~ms} ; S D=470.98$ $\mathrm{ms})$ and mismatching traits $(M=1403.73 \mathrm{~ms} ; S D=570.95$ $\mathrm{ms})$ in the control condition were not significant, $F(1,74)=$ 0.03 , n.s. $F(1,74)=0.70$, n.s.

\section{Discussion}

This study investigated the relationship between mortality salience and self-ingroup overlap on the basis of the response time paradigm. Within the framework of Smith et al.'s (1999) approach, if people respond to self-group matching traits faster, the two concepts are interpreted to be overlapping. With this reasoning, we predicted that mortality salience would enhance the overlaps of mental representations between the self and the ingroup.

The results indicated that our hypothesis was confirmed. The self-ingroup matching traits were more facilitated than the mismatching traits after the manipulation of mortality salience, and no such effect was found in self-outgroup connections. These findings of the present article contribute to research on terror management theory, which states that the fear of death invokes increased ingroup attachment whereby one defends one's cultural worldview. The theory assumes that the self-ingroup connection has a beneficial effect on self-preservation, thus having a stronger effect after the self-threat. While studies have shown that mortality salience leads people to defend their cultural worldview by identifying with their ingroups (Castano et al., 2002; Harmon-Jones et al., 1996), the present study found evidence that people strengthen the association with ingroups in the face of mortality salience.

Although the patterns of results show that the self- ingroup matching effect was larger in the mortality salient condition, it was also true that the matching traits in the mortality salient condition were slower than the matching traits in the control condition. Because of that, it might seem at first that the self-ingroup overlap was not enhanced in the mortality salient condition. However, it is reasonable to suppose that the manipulation of mortality salience increased the baselines of average response times for trait judgments. When death thoughts are activated, people strengthen the cognitive overlap between the self and ingroup to validate the cultural worldview. This need to cling to the ingroup influenced participants' trait judgments and it became more important in ingroup judgments whether the traits could also apply to the self. As a result, it can be considered that participants in the mortality salient condition took longer time to carefully work on the assignment. This might explain why mortality salience manipulation produced a main effect in the current study, and thus the present findings can be interpreted as demonstrating that mortality salience enhances the overlaps of the self and ingroup.

A recent theoretical framework proposed by Castano and Dechesne (2005), suggests that social identification processes as anxiety-buffer can be elucidated by two perspectives. A first perspective particularly focuses on selfesteem, and it has the same basic assumption with social identity theory (Tajfel \& Turner, 1979). This perspective suggests that social identities serve as anxiety-buffering mechanisms because positive group-based self-esteem appeases existential concerns. Arndt, Greenberg, Schimel, Pyszczynski, and Solomon's (2002) work support this argument by showing that mortality salience increases ingroup identification, but leads to disidentification with ingroups when those groups are framed negatively. A second perspective proposed that social identity serves as an anxiety-buffer because it provides the individual with an extension of the self. Given the two theoretical accounts of social identity processes, the present data seems to support the latter, because the effect of self-ingroup overlap was not moderated by trait-valence. It is our contention that the participants sought connection with their ingroups to extend the self and to overcome the limitations of their individual identity.

It is worth noting that we employed the minimal group paradigm (Tajfel et al., 1971) in the classification of partici- 
pants. The use of a minimal group could be viewed as evidence that people may even increase their connection with a new ingroup in the presence of mortality salience. Harmon-Jones et al. (1996) found that mortality salience intensified a perceived ingroup similarity between minimal groups. Along with the results of Harmon-Jones et al. (1996), the results in the present study support the assertion that minimal ingroups could serve the same worldview defense functions as salient ingroups. Furthermore, the fact that we used minimal groups has another implication for research on self-ingroup overlap. In the minimal group condition, the participants have no prior knowledge about their ingroups. This implies that the ingroup knowledge was characterized by only self-concepts, thereby resulting in overlaps of the two concepts. Therefore, self-ingroup overlap can be regarded as the ingroup's assimilation to the self (Cadinu \& Rothbart, 1996; Clement \& Krueger, 2002), rather than assuming that the results attest to the assimilation of the self into the ingroup (Tajfel \& Turner, 1979; Turner et al., 1987).

The overall pattern of results obtained in this study is consistent with our predictions, but, nonetheless, our study had a major difference with the preceding findings: in our experiment, self-ingroup matching effect was not found in the control condition. In contrast, typical studies in this area have obtained self-ingroup matching effects without any manipulation of self-threat (Smith \& Henry, 1996; Smith et al., 1999; Otten \& Epstude, 2006; Cadinu \& De Amicis, 1999). This inconsistency in the findings may reflect the difference between the group settings. Previous studies used existing groups to examine self-ingroup overlap. For example, Smith et al. (1999) used groups of Greeks/NonGreeks, which were thought to be moderately salient to the participants. Unlike these studies, our method of minimal groups provides neither prior information about the groups nor intergroup contacts between group members. Accordingly, the participants in this study may have been less motivated to become attached to their minimal ingroups than their salient ingroups, and self-ingroup overlap was not found unless self-concepts were threatened.

One potential limitation of the present study is the interpretation of the mortality salience effect. Although we presume that thoughts of death are responsible for the effects observed in this study, negative mood could be pointed out as an alternative account of responses to mortality salience.
Mood check items were not included in our experiment; therefore, we cannot provide a definitive answer to this question. However, available findings are inconsistent with this interpretation. The manipulation of mortality salience does not typically cause negative mood, and it sometimes induces positive mood (Greenberg, Solomon, \& Pyszczynski, 1997; Pyszczynski, Greenberg, Solomon, Arndt, \& Schimel, 2004). The literature demonstrated that even if a negative mood was caused, other negative primes do not produce the same effects as mortality salience does. Consistent with this view, in some cases negative mood has an adverse effect on cultural worldview defense (Greenberg et al., 1995). Taken together, it seems difficult to explain the observed results by attributing them to the effects of negative mood.

In conclusion, the results confirmed the phenomenon that mortality salience increased overlaps of the self and ingroup concepts. In the face of danger, people are likely to feel a strong connection to their ingroups for the purpose of self-protection. Without threats to the self, minimal ingroups could not serve the functions of cultural worldview defense, but they become useful resource to cope with self-threats. We found this evidence in minimal groups; therefore, one direction for future research might be to compare this overlap process with more competitive group situations. Research by Landau, Solomon, Greenberg, Cohen, Pyszczynski, Arndt, Miller, Ogilvie, and Cook (2004) showed that subliminal exposure to WTC (World Trade Center) and 911 among American participants brought a significant increase in the accessibility of the death-related thoughts after the 9/11 attacks. At the same time, the reminder of these events heightened the support for the president at that time, George W. Bush. As we face a growing threat from outgroups such as seen on $9 / 11$, it is likely that we would further reinforce the ties with ingroups and aggravate a personal relationship between the self and outgroup. Additional research is required to replicate the findings and further investigate self-defense mechanisms that occur when people are under threat.

\section{References}

Arndt, J., Greenberg, J., Schimel, J., Pyszczynski, T., \& Solomon, S. (2002). To belong or not to belong, that is the question: Terror management and identification with gender and ethnicity. Journal of Personality and 
Social Psychology, 83, 26-43.

Aron, A., Aron, E. N., Tudor, M., \& Nelson, G. (1991). Close relationships as including other in the self. Journal of Personality and Social Psychology, 60, 241-253.

Baumeister, R. F., \& Leary, M. R. (1995). The need to belong: Desire for interpersonal attachments as a fundamental human motivation. Psychological Bulletin, 117, 497-529.

Cadinu, M. R., \& De Amicis, L. (1999). The relationship between the self and the ingroup: When having a common conception helps. Swiss Journal of Psychology, 58, 226-232.

Cadinu, M. R., \& Rothbart, M. (1996). Self-anchoring and differentiation processes in the minimal group setting. Journal of Personality and Social Psychology, 70, 661677.

Castano, E., \& Dechesne, M. (2005). On defeating death: Group reification and social identification as immortality strategies. European Review of Social Psychology, 16, 221-255.

Castano, E., Yzerbyt, V., Paladino, M., \& Sacchi, S. (2002). I belong, therefore, I exist: Ingroup identification, ingroup entitativity, and ingroup bias. Personality and Social Psychology Bulletin, 28, 135-143.

Clement, R. W., \& Krueger, J. (2002). Social categorization moderates social projection. Journal of Experimental Social Psychology, 39, 279-299.

Correll, J., \& Park, B. (2005). A model of the ingroup as a social resource. Personality and Social Psychology Review, 9, 341-359.

Dechesne, M., Janssen, J., \& van Knippenberg, A. (2000). Derogation and distancing as terror management strategies: The moderating role of need for closure and permeability of group boundaries. Journal of Personality and Social Psychology, 79, 923-932.

Fazio, R. H. (1991). A practical guide to the use of response latency in social psychological research. In $\mathrm{C}$. Hendrick \& M. S. Clark (Eds.), Research methods in personality and social psychology: Review of personality and social psychology (pp. 74-97). Newbury Park, CA: Sage.

Florian, V., Mikulincer, M., \& Hirschberger, G. (2001). Validation of personal identity as a terror management mechanism: Evidence that sex-role identity moderates mortality salience effects. Personality and Social
Psychology Bulletin, 27, 1011-1022.

Greenberg, J., Pyszczynski, T., Solomon, S., Pinel, E., Simon, L., \& Jordan, K. (1993). Effects of self-esteem on vulnerability-denying defensive distortions: Further evidence of an anxiety-buffering function of self-esteem. Journal of Experimental Social Psychology, 29, 229-251.

Greenberg, J., Pyszczynski, T., \& Solomon, S. (1986). The causes and consequences of a need for self-esteem: A terror management theory. In R. F. Baumeister (Ed.), Public self and private self (pp. 189-207). New York; Tokyo: Springer Verlag.

Greenberg, J., Pyszczynski, T., Solomon, S., Rosenblatt, A., Veeder, M., Kirkland, S., \& Lyon, D. (1990). Evidence for terror management: II. The effects of mortality salience on reactions to those who threaten or bolster the cultural worldview. Journal of Personality and Social Psychology, 58, 308-318.

Greenberg, J., Simon, L., Harmon-Jones, E., Solomon, S., Pyszczynski, T., \& Lyon, D. (1995). Testing alternative explanations for mortality salience effects: Terror management, value accessibility, or worrisome thoughts? European Journal of Social Psychology, 25, 417-433.

Greenberg, J., Simon, L., Porteus, J., Pyszczynski, T., \& Solomon, S. (1995). Evidence of a terror management function of cultural icons: The effects of mortality salience on the inappropriate use of cherished cultural symbols. Personality and Social Psychology Bulletin, 21, 1221-1228.

Greenberg, J., Solomon, S., \& Pyszczynski, T. (1997). Terror management theory of self-esteem and cultural worldviews: Empirical assessments and conceptual refinements. In P. M. Zanna (Ed.), Advances in experimental social psychology (pp. 61-139). San Diego, CA: Academic Press.

Greenberg, J., Solomon, S., Pyszczynski, T., Rosenblatt, A., Burling, J., Lyon, D., Simon, L., \& Pinel, E. (1992). Why do people need self-esteem? Converging evidence that self-esteem serves an anxiety-buffering function. Journal of Personality and Social Psychology, 63, 913922.

Harmon-Jones, E., Greenberg, J., Solomon, S., \& Simon, L. (1996). The effects of mortality salience on intergroup bias between minimal groups. European Journal of Social Psychology, 26, 677-681.

Knowles, M. L., \& Gardner, W. L. (2008). Benefits of 
membership: The activation and amplification of group identities in response to social rejection. Personality and Social Psychology Bulletin, 34, 1200-1213.

Landau, M. J., Solomon, S., Greenberg, J., Cohen, F., Pyszczynski, T., Arndt, J., Miller, C. H., Ogilvie, D. M., \& Cook, A. (2004). Deliver us from evil: The effects of mortality salience and reminders of 9/11 on support for President George W. Bush. Personality and Social Psychology Bulletin, 30, 1136-1150.

Nodera, A., Karasawa, K., Numazaki, M., \& Takabayashi, K. (2007). An examination of the promoter of gender role stereotype-activation based on terror management theory. Japanese Journal of Social Psychology, 23, 195201.

Otten, S., \& Epstude, K. (2006). Overlapping mental representations of self, ingroup, and outgroup: Unraveling self-stereotyping and self-anchoring. Personality and Social Psychology Bulletin, 32, 957-969.

Pyszczynski, T., Greenberg, J., Solomon, S., Arndt, J., \& Schimel, J. (2004). Why do people need self-esteem? A theoretical and empirical review. Psychological Bulletin, 130, 435-468.

Saito, T., Nakamura, T., Endo, T., \& Yokoyama, M. (2001). Standardization of Big Five scales using the adjective check list. Kyushu University Psychological Research, 2,
135-144.

Smith, E. R., Coats, S., \& Walling, D. (1999). Overlapping mental representations of self, in-group, and partner: Further response time evidence and a connectionist model. Personality and Social Psychology Bulletin, 25, 873-882.

Smith, E. R., \& Henry, S. (1996). An in-group becomes part of the self: Response time evidence. Personality and Social Psychology Bulletin, 22, 635-642.

Tajfel, H., Billig, M. G., Bundy, R. P., \& Flament, C. (1971). Social categorization and intergroup behavior. European Journal of Social Psychology, 1, 149-178.

Tajfel, H., \& Turner, J. C. (1979). An integrative theory of intergroup conflict. In S. Worchel \& W. G. Austin (Eds.), The social psychology of intergroup relations (pp. 33-47). Monterey, CA: Brooks-Cole.

Taubman Ben-Ari, O., Florian, V., \& Mikulincer, M. (1999). The impact of mortality salience on reckless driving: A test of terror management mechanisms. Journal of Personality and Social Psychology, 76, 35-45.

Turner, J. C., Hogg, M. A., Oakes, P. J., Reicher, S. D., \& Wetherell, M. S. (1987). Rediscovering the social group: A self-categorization theory. Oxford \& New York: Basil Blackwell. 


\title{
死の顕現性が自己と内集団の概念連合に与える影響
}

\author{
渡辺匠 \\ 唐 沢 かおり \\ 東京大学大学院人文社会系研究科 \\ 東京大学大学院人文社会系研究科
}

\begin{abstract}
本研究は存在务威管理理論の観点から, 死の顕現性が自己と内集団の概念連合に与える影響について検証 をおこなった。存在肙威管理理論では, 死の顕現性が高まると文化的世界観の防衛反応が生じると仮定して いる。これらの仮定にもとづき，人々は死の蓇威にさらされると，自己と内集団の概念連合を強めるかどう かを調べた。死の顕現性は質問紙を通じて操作し, 内集団との概念連合は反応時間パラダイムをもちいて測 定した。その結果, 死の劦威が喚起された参加者は, 自己概念と内集団概念で一致した特性語に対する判断 時間が一致していない特性語よりも速くなることが明らかになった。その一方，死の劦威が喚起されても， 自己概念と外集団概念で一致した特性語に対する判断時間は一致していない特性語よりも速くはならないこ とが示された。これらの結果は, 死の顕現性が高まると, 自己と内集団の概念連合が強化されることを示唆 している。考察では, 自己と内集団の概念連合と存在脅威管理プロセスとの関係性について議論した。
\end{abstract}

キーワード：自己, 内集団, 概念連合, 死の顕現性, 存在脅威管理理論 